\title{
The contribution of CHEK2 to the TP53-negative Li-Fraumeni
} phenotype

\author{
Marielle WG Ruijs ${ }^{1,3}$, Annegien Broeks ${ }^{2}$, Fred H Menko ${ }^{3}$, \\ Margreet GEM Ausems ${ }^{4}$, Anja Wagner ${ }^{5}$, Rogier Oldenburg ${ }^{5}$, Hanne Meijers- \\ Heijboer $^{3,5}$, Laura J van't Veer ${ }^{2}$ and Senno Verhoef*1
}

\begin{abstract}
Address: ${ }^{1}$ Family Cancer Clinic, The Netherlands Cancer Institute, Amsterdam, The Netherlands, ${ }^{2}$ Department of Experimental Therapy, The Netherlands Cancer Institute, Amsterdam, The Netherlands, ${ }^{3}$ Department of Clinical Genetics and Human Genetics, VU University Medical Centre, Amsterdam, The Netherlands, ${ }^{4}$ Department of Medical Genetics, University Medical Centre, Utrecht, The Netherlands and ${ }^{5}$ Department of Clinical Genetics, Erasmus Medical Centre, Rotterdam, The Netherlands

Email: Marielle WG Ruijs - mwg.ruijs@vumc.nl; Annegien Broeks - a.broeks@nki.nl; Fred H Menko - fh.menko@vumc.nl; Margreet GEM Ausems - M.G.E.M.Ausems@umcutrecht.nl; Anja Wagner - a.wagner@erasmusmc.nl; Rogier Oldenburg - r.oldenburg@erasmusmc.nl; Hanne Meijers-Heijboer - H.Meijers@vumc.nl; Laura J van't Veer - l.vt.veer@nki.nl; Senno Verhoef* - s.verhoef@nki.nl

* Corresponding author
\end{abstract}

Published: 17 February 2009

Hereditary Cancer in Clinical Practice 2009, 7:4 doi:10.1186/1897-4287-7-4
Received: 14 November 2008 Accepted: 17 February 2009

This article is available from: http://www.hccpjournal.com/content/7///4

(c) 2009 Ruijs et al; licensee BioMed Central Ltd.

This is an Open Access article distributed under the terms of the Creative Commons Attribution License (http://creativecommons.org/licenses/by/2.0), which permits unrestricted use, distribution, and reproduction in any medium, provided the original work is properly cited.

\begin{abstract}
Background: $\mathrm{CHEK2}$ has previously been excluded as a major cause of Li-Fraumeni syndrome (LFS). One particular CHEK2 germline mutation, c. I I00delC, has been shown to be associated with elevated breast cancer risk. The prevalence of CHEK2*II00delC differs between populations and has been found to be relatively high in the Netherlands. The question remains nevertheless whether CHEK2 germline mutations contribute to the Li-Fraumeni phenotype.
\end{abstract}

Methods: We have screened 65 Dutch TP53-negative LFS/LFL candidate patients for CHEK2 germline mutations to determine their contribution to the LFS/LFL phenotype.

Results: We identified six index patients with a CHEK2 sequence variant, four with the c. I I00delC variant and two sequence variants of unknown significance, p.Phe328Ser and c.1096-?_1629+?del.

Conclusion: Our data show that CHEK2 is not a major LFS susceptibility gene in the Dutch population. However, CHEK2 might be a factor contributing to individual tumour development in TP53-negative cancer-prone families.

\section{Background}

Li-Fraumeni syndrome (LFS) is a rare autosomal dominant cancer syndrome predisposing for bone and soft tissue sarcoma, breast cancer, brain tumour, adrenocortical carcinoma and leukaemia [1]. The classical LFS criteria are: a proband with sarcoma aged under 45 years and a first-degree relative with any cancer aged under 45 years, plus a first or second-degree relative in the same lineage with any cancer under the age of 45 years or sarcoma at any age [2]. In addition, Li-Fraumeni-like syndrome (LFL) criteria have been formulated as a proband with any childhood tumour or a sarcoma, brain tumour or adrenocortical tumour diagnosed under 45 years of age and a first or second-degree relative in the same lineage with a typical 
LFS tumour at any age, plus a first or second-degree relative in the same lineage younger than 60 years with any cancer [3]. Less stringent LFL criteria were formulated by Eeles et al. as two first or second-degree relatives with typical LFS-extended tumours (classical LFS tumours plus melanoma, prostate cancer and pancreatic cancer) at any age [4]. The Chompret criteria for TP53 germline mutation testing have been updated in 2008 as: (1) a proband with a tumour belonging to the LFS tumour spectrum (sarcomas, brain tumours, pre-menopausal breast cancer, adrenocortical carcinoma, leukaemia, lung bronchoalveolar cancer) cancer before 46 years of age and at least one first or second-degree relative with an LFS tumour before 56 years of age or multiple tumours; or (2) a proband with multiple tumours two of which belong to the narrow LFS tumour spectrum and the first of which occurred before 46 years of age; or (3) a patient with adrenocortical carcinoma or a patient with breast cancer before 36 years of age without $B R C A$ mutation, irrespective of the family history [5].

In 1990 germline mutations in the TP53 gene were described in LFS [6]. So far, 419 TP53-positive families have been reported (IARC mutation database, R13, November 2008 [7]). At present, in approximately $75 \%$ of LFS and $40 \%$ of LFL families, a germline TP53 mutation can be detected [8]; i.e. $25 \%$ to $60 \%$ of LFS/LFL families do not carry a detectable germline TP53 mutation, implying the existence of alternative LFS susceptibility genes.

CHEK2 is a cell cycle checkpoint kinase involved in DNA repair, cell death and cell cycle control by stabilizing the p53 protein [9]. In 1999 Bell et al. first described the possible association of the CHEK2 gene with Li-Fraumeni syndrome [10]. Subsequent studies have addressed the possible contribution of CHEK2 germline mutations to LFS and LFL syndrome, but could not confirm CHEK2 as a major gene involved in LFS [10-18].

In other studies, the specific CHEK2 c.1100delC frameshift mutation was shown to be associated with an elevated breast cancer risk [19-22] and it has been suggested that it contributes to a hereditary breast and colorectal cancer phenotype [23]. The prevalence of this c.1100delC mutation seems to differ according to ethnic backgrounds and populations and is relatively high in the Netherlands $[19,24]$. We have investigated the CHEK2 gene mutation status of 65 index patients from 65 Dutch LFS/LFL families and families suggestive of LFS who had tested negative for TP53 germline mutations, to determine the contribution of CHEK2 germline mutations to the phenotype in those families.

\section{Methods}

All 65 affected index patients had been assessed and counselled in various clinical genetics centres because of the occurrence of different cancer types related to LFS and had as a consequence been tested for TP53 germline mutations. On the basis of the available clinical data, the TP53negative families were classified into 3 groups: 1 ) classical LFS [2], 2) LFL syndrome according to Birch [3] or Eeles [4] and 3) LFS-suggestive, including childhood onset (under 18 years) sarcoma or brain tumours, two or more primary tumours at any age, two first-degree relatives with a tumour at any age, of which at least one relative has a typical LFS tumour or breast cancer under 30 years of age (without BRCA1 or BRCA2 mutations) (Table 1). In families with multiple breast cancer cases and individuals with breast and ovarian cancer, BRCA1 or BRCA2 mutations were excluded, according to standard procedures. Details are available on request.

DNA from peripheral blood lymphocytes was isolated according to standard procedures. Screening for TP53 germline mutations was performed by sequence analysis of all coding exons (2-11) including flanking intron-exon boundaries (details are available on request) and multiplex ligation-dependent probe amplification (MLPA) [25] (TP53 MLPA KIT, MRC Holland). In 34 TP53-negative LFS, LFL, or LFS-suggestive families all exons and flanking intron-exon boundaries of the CHEK2 gene were investigated using denaturing gradient gel electrophoresis (DGGE, see Table 1) [26]. All possible candidate variants, identified as aberrant DGGE fragments, were confirmed by sequence analysis. To avoid amplification of pseudogenes, a long range PCR was performed first for exons 10 to 14 , followed by a nested PCR. Data on exons 1-10 were obtained for all patients, on exons 11-14 for 29 of the 34 individuals. All 65 TP53-negative individuals were screened for the c.1100delC CHEK2 mutation and CHEK2 DNA rearrangements by multiplex ligation-dependent probe amplification (MLPA, see Table 1). Details are available on request (CHEK2 MLPA KIT, MRC Holland). Mutation analysis was performed using the following reference sequence: CHEK2 (AF086904.1, GI:3982839, http://www.ncbi.nlm.nih.gov/entrez/viewer.fcgi?db=nuc core\&id=3982839).

Sequence variants were weighted according to their potential pathogenicity. Three silent sequence variants were seen and not further analysed: c.252A>G, p.Glu84Glu in exon 1 , a previously reported silent polymorphism [15], found once, c.1566C $>T$, p.Pro522Pro and c.1608A $>\mathrm{G}$, p.Pro536Pro, both in exon 14, found in five and seven families, respectively. For these three variants two splice site prediction programs were used, NetGene2 Server http://www.cbs.dtu.dk/services/NetGene2/ and BDGP Splice Site Prediction/Neural Network http://www.fruit 
Table I: Number of TP53 negative families available for CHEK2 gene analysis divided into 3 groups: LFS, LFL, or LFS-suggestive family history $(n=65)$, including the cancer type in tested individuals.

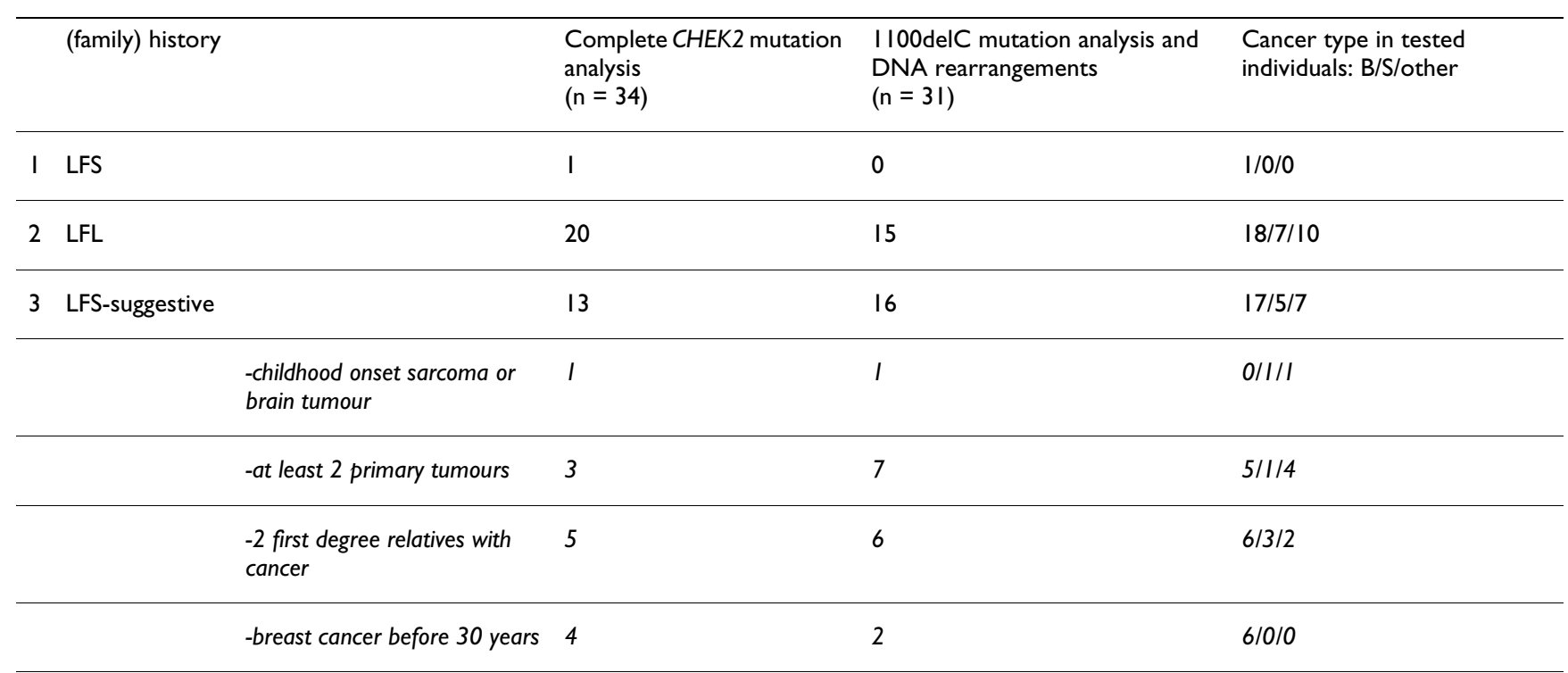

LFS $=$ Li-Fraumeni syndrome

$\mathrm{LFL}=\mathrm{Li}$-Fraumeni-like syndrome according to Birch or Eeles

$\mathrm{B}=$ breast cancer

$\mathrm{S}=$ sarcoma

Other = other cancers, including adrenal cortical tumour, bladder cancer, brain tumour, colon cancer, kidney cancer, leukaemia, lung cancer,

melanoma, non-Hodgkin lymphoma, ovarian cancer and thyroid cancer.

fly.org/seq tools/splice.html; no alternative splice sites were predicted.

When possible, the presence of a sequence variant detected in an index patient was investigated in other affected relatives. A control group of 150 anonymous Dutch (male and female) blood donors was analysed by DGGE to determine the prevalence of the sequence variants in a general population sample.

A chi-square test was used to determine the statistical significance of the proportion of CHEK2 mutation carriers in our study group compared to healthy controls.

\section{Results and discussion}

Sixty-five TP53-negative individuals from 65 families were screened for the CHEK2 1100delC germline mutation and DNA rearrangements. Thirty-four of these individuals were screened comprehensively by DGGE for CHEK2 mutations. Six index patients were found to carry a possibly pathogenic germline CHEK2 sequence variant.

The c.1100delC in exon 10 of the CHEK2 gene, a mutation located in the kinase domain of the gene and abolishing the kinase activity of the protein, was detected in four index patients. In one family, a classical LFS family, the c.1100delC was detected in a patient who developed breast cancer at the age of 48 years (Figure 1A), which is in line with the c.1100delC acting as a low penetrance breast cancer susceptibility allele [19]. Relatives with a $50 \%$ chance of being a c.1100delC carrier in this family who had developed breast cancer were not available for testing. However, it is not likely to be the LFS-causing mutation in this family, considering the absence of the c.1100delC in the patient's son who developed a sarcoma at 15 years of age. In an LFL and LFS-suggestive family, the patients identified as carrying the c.1100delC had breast cancer (Figure 1B and 1D); in a fourth family, a LFS-suggestive family, the patient identified with the c.1100delC sequence variant had both breast and colorectal cancer (Figure 1C). No additional material was available for testing to see if and how the mutation segregates in these families. In all four of the c.1100delC families, this sequence variant seemed to be associated with breast cancer or breast and colorectal cancer, rather than LFS. The reported frequency of the CHEK c.1100delC in Dutch controls is $1.4 \%$, in Dutch breast cancer patients not selected for family history $2.5 \%$ and in Dutch BRCA1/2-negative families with breast cancer $4.9 \%[19]$. In our sample the frequency was $6.2 \%(4 / 65)$, significantly different from that for healthy controls $(\mathrm{p}=0.006)$.

Another sequence variant, c.983T $>C$, p.Phe328Ser in exon 8 , localised in the kinase domain of the gene, was detected in a female patient who had developed a leiomyosarcoma at 2 years of age and a schwannoma at 27 years of age (Figure 1E). The family of the index patient fulfilled the LFL criteria (Eeles [4]). The parents of the index 
A. LFS family, c.1100delC

I

I

II

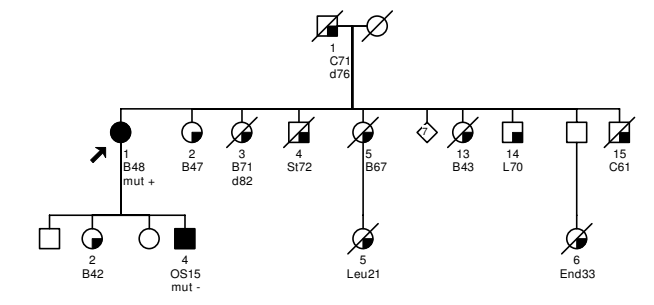

B. LFL family, c.1100delC

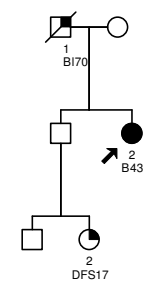

C. LFS-suggestive family, c.1100delC

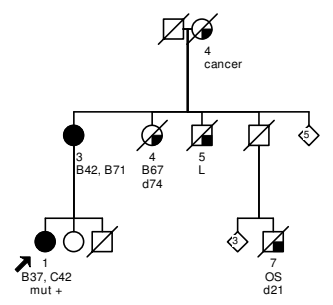

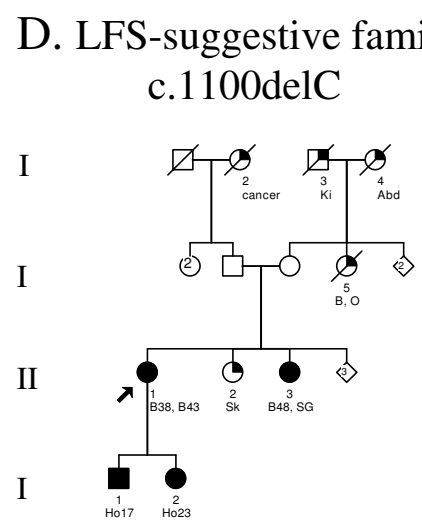

D. LFS-suggestive family, c.1100delC

E. LFL family, p.Phe328Ser

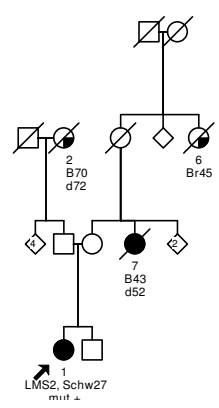

F. LFL family, c.1096-?_1629+?del

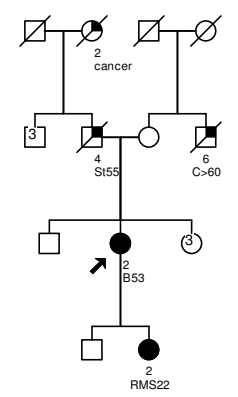

Figure I

Pedigrees of germline CHEK2 sequence variation families. Square symbols indicate males, round symbols indicate females, line across symbol means deceased individual. Filled symbols indicate affected individuals with diagnosis confirmed by pathology reports. A quarterly filled symbol indicate affected individuals with diagnosis by family history. Tumour type and age at diagnosis of the tumours are indicated below the individual identifiers, $d=$ age of death. The index patient is indicated with an arrow. Abd = abdominal cancer, $\mathrm{B}=$ breast cancer, $\mathrm{BI}=$ bladder cancer, $\mathrm{Br}=$ brain tumour, $\mathrm{C}=$ colorectal cancer, cancer $=$ cancer of unknown origin, DFS = dermatofibrosarcoma, End = endometrial cancer, Ho $=$ Hodgkin lymphoma, $\mathrm{Ki}=\mathrm{kidney}$ cancer, $\mathrm{L}=$ lung cancer, Leu = leukaemia, LMS = Leiomyosarcoma, O = ovarian cancer, Oes = oesophagus carcinoma, OS = osteosarcoma, RMS = rhabdomyosarcoma, Schw = schwannoma, SG = salivary gland cancer, Sk = skin cancer, St = stomach cancer, mut $+=$ mutation detected, mut $-=$ mutation excluded.

patient are both healthy and over 60 years of age. A maternal aunt died of breast cancer at 45 years of age and a sister of the index patient's maternal grandmother died of a brain tumour; no material was available for testing. Under the assumption that these two affected family members were carriers of the mutation, penetrance would be incomplete with non-penetrance exhibited by two older healthy obligate mutation carriers. The hypothesis that the exon 8 mutation caused the complete LFL phenotype in this family is unlikely although a de novo mutation, contributing to the disease in the index patient, cannot be excluded. The p.Phe328Ser missense mutation has not been described in the literature before and was not found in 150 healthy Dutch controls. The phenylalanine in this position is conserved in mice and frogs but not in either zebrafish or C. Elegans (Ensembl, v39-Jun 2006 [27]).

One CHEK2 DNA rearrangement was found, c.1096?_1629+?del, a deletion of exons $10-14$ of the gene. The family fulfilled the LFL criteria according to Birch[3] and the index patient developed breast cancer at the age of 55 years. A deletion of this size in the kinase domain of the gene will probably abolish the kinase activity. This deletion has not been described in the literature before. A deletion of exon 9-10 predicting protein truncation at codon 381 was discovered as a founder mutation among patients of Czecholovakian ancestry with breast cancer [17]. Unfortunately, no material from the daughter who developed a rhabdomyosarcoma at 22 years of age was 
available. Four sibs of the index patient were healthy; her father developed stomach cancer at 55 years of age.

So far, 8 studies have been published on CHEK2 analysis of a total of 196 TP53-negative LFS families or families suggestive of LFS (Table 2) [10-17]. Of the seven variants presented, only the c.1100delC, the p.Ile157Thr and the p.Arg145Trp mutation are of reported functional significance. Bell et al [10] found the p.Ile157Thr in an index patient with three primary cancers; no other family members were tested. Allinen et al. [11] screened the CHEK2 gene in 21 LFS/LFL families and only found the p.Ile157Thr mutation; since it was found in healthy controls as well, they concluded that it does not contribute to an LFL-associated breast cancer risk. Some authors found an association between the p.Ile157Thr mutation and risk of female breast cancer [28-30], others found no association [31]. The p.Arg145Trp, leading to a destabilised protein, was described in a Li-Fraumeni-like kindred; it was only tested in one family-member with a sarcoma at 20 years and breast cancer at 42 years. It was not found in 200 controls [13].

In our study six index patients were found to carry a CHEK2 sequence variant by screening 65 TP53-negative index patients, with no evidence that the sequence variants found caused the complete LFS phenotype in their families. Our data are in line with the hypothesis that the CHEK2 c.1100delC might be associated with an elevated breast cancer risk $[19,20]$, and possibly with a breast and colorectal cancer phenotype [23] or more generally a multi-organ cancer susceptibility [32]. We propose that the germline CHEK2 sequence variants contribute to tumour development in the index patients. Without these tumours, the families would not have fulfilled the established LFS/LFL criteria and TP53 germline mutation testing would not have been indicated. In this way, the individual CHEK2 sequence variants may contribute to the Li-Fraumeni phenotype seen in these families.

Because only $75 \%$ of classical LFS families and $40 \%$ of LFL families have germline TP53 mutations, research groups have looked at candidate genes like Bcl10 [33], CDKN2 [34,35], TP63 [12], PTEN [34,36], CHEK1 [10,14] and $B A X$ [37]; no possible alternative LFS genes were found.

Two polymorphisms, p.Arg72Pro (TP53 gene) and SNP309 T>G (MDM2 gene), have been shown to have a modifying effect, resulting in an earlier age of onset of cancer in TP53 mutation carriers [38,39]; there is even a synergistic effect when both polymorphisms are present. These are proposed examples of modifying factors or low penetrance gene mutations that play a role in age of onset and tumour clustering in cancer-prone families [40]. In

Table 2: Literature on CHEK2 analysis in LFS and LFS-related families

\begin{tabular}{|c|c|c|c|c|}
\hline & $\begin{array}{l}\text { number of families tested: LFS/ } \\
\text { LFL/suggestive }\end{array}$ & total CHEK2 analysis & $\begin{array}{l}\text { CHEK2 I I00delC analysis + } \\
\text { DNA rearrangements }\end{array}$ & mutations found \\
\hline Allinen et al. [I I] & $1 / 20 / 0$ & 21 & 0 & p.llel57Thr \\
\hline Bell et al. [10] & $4 / 18^{*}$ & 22 & 0 & $\begin{array}{l}\text { c.II00delC } \\
\text { p.llel57Thr }\end{array}$ \\
\hline Bougeard et al. [12] & $0 / 4 / 0$ & 4 & 0 & - \\
\hline Lee et al. [13] & $10 / 49 *$ & 59 & 0 & $\begin{array}{l}\text { p.Arg | 45Trp } \\
\text { p.Arg3Trp } \\
\text { p.lle I57Thr }\end{array}$ \\
\hline Siddiqui et al. [16] & $1 / 13 / 1$ & 0 & 15 & - \\
\hline Sodha et al. [15] & $5 / 21 / 0$ & 26 & 0 & $\begin{array}{l}\text { IVS5- I IG>A } \\
\text { c. } 483-485 \text { delAGA }\end{array}$ \\
\hline Vahteristo et al. [14] & $1 / 6 / 32$ & 39 & 0 & c.IIO0delC \\
\hline Walsh et al. [16] & $3 / 7 / 0$ & 10 & & - \\
\hline our results & $1 / 35 / 29$ & 34 & 31 & $\begin{array}{l}\text { p.Phe328Ser } \\
\text { c.|l00delC } \\
\text { c.108I-?_|77|+?del }\end{array}$ \\
\hline
\end{tabular}

$*=\mathrm{LFL}$ and LFS-suggestive combined, subdivision not further mentioned 
our present study group, we investigated the possible modifier effects of these polymorphisms but found no association with an earlier age of tumour onset [41] (p.Arg72Pro, data not shown). We did find a larger proportion of homozygotes for the G-allele of MDM2 SNP309 in our TP53-negative group, suggesting a modifier effect on the TP53 negative Li-Fraumeni phenotype.

\section{Conclusion}

Our data illustrate that CHEK2 is not a major LFS susceptibility gene in the Dutch population. The CHEK2 gene might be a factor contributing to individual tumour development in families that are subsequently recognised as having a Li-Fraumeni phenotype. Although many genes have been excluded as alternative LFS genes, many more modifiers or low penetrance susceptibility genes might occur in families showing a Li-Fraumeni phenotype.

\section{Competing interests}

The authors declare that they have no competing interests.

\section{References}

I. Li FP, Fraumeni JF Jr: Soft-tissue sarcomas, breast cancer, and other neoplasms. A familial syndrome? Ann Intern Med I969, 71:747-752.

2. Li FP, Fraumeni JF Jr, Mulvihill JJ, Blattner WA, Dreyfus MG, Tucker MA, Miller RW: A cancer family syndrome in twenty-four kindreds. Cancer Res 1988, 48:5358-5362.

3. Birch JM, Hartley AL, Tricker KJ, Prosser J, Condie A, Kelsey AM, Harris M, Jones PH, Binchy A, Crowther D, Craft AW, Eden OB, Evans DGR, Thompson E, Mann JR, Martin J, Mitchell ELD, SantibanezKoref MF: Prevalence and diversity of constitutional mutations in the p53 gene among $2 \mathrm{I} \mathrm{Li-Fraumeni} \mathrm{families.} \mathrm{Cancer}$ Res 1994, 54:1298-1304.

4. Eeles RA: Germline mutations in the TP53 gene. Cancer Surv 1995, 25:101-124.

5. Bougeard G, Sesboue R, Baert-Desurmont S, Vasseur S, Martin C, Tinat J, Brugieres L, Chompret A, de Paillerets BB, Stoppa-Lyonnet D, Bonaiti-Pellie C, Frebourg T: Molecular basis of the Li-Fraumeni syndrome: an update from the French LFS families. J Med Genet 2008, 45:535-538.

6. Malkin D, Li FP, Strong LC, Fraumeni JF Jr, Nelson CE, Kim DH, Kassel J, Gryka MA, Bischoff FZ, Tainsky MA, Friend SH: Germ line p53 mutations in a familial syndrome of breast cancer, sarcomas, and other neoplasms. Science 1990, 250:1233-I238.

7. Petitjean A, Mathe E, Kato S, Ishioka C, Tavtigian SV, Hainaut P, Olivier M: Impact of mutant p53 functional properties on TP53 mutation patterns and tumor phenotype: lessons from recent developments in the IARC TP53 database. Hum Mutat 1990, 28:622-629.

8. Varley JM: Germline TP53 mutations and Li-Fraumeni syndrome. Hum Mutat 2003, 2 I:3 13-320.

9. Bartek J, Falck J, Lukas J: CHK2 kinase - a busy messenger. Nat Rev Mol Cell Biol 200I, 2:877-886.

10. Bell DW, Varley JM, Szydlo TE, Kang DH, Wahrer DC, Shannon KE, Lubratovich M, Verselis SJ, Isselbacher KJ, Fraumeni JF, Birch JM, Li FP, Garber JE, Haber DA: Heterozygous germ line hCHK2 mutations in Li-Fraumeni syndrome. Science 1999, 286:2528-253I.

II. Allinen M, Huusko P, Mantyniemi S, Launonen V, Winqvist R: Mutation analysis of the CHK2 gene in families with hereditary breast cancer. Br J Cancer 200I, 85:209-2I2.

12. Bougeard G, Limacher JM, Martin C, Charbonnier F, Killian A, Delattre O, Longy M, Jonveaux P, Fricker JP, Stoppa-Lyonnet D, Flaman JM, Frebourg T: Detection of I I germline inactivating TP53 mutations and absence of TP63 and HCHK2 mutations in 17 French families with Li-Fraumeni or Li-Fraumeni-like syndrome. J Med Genet 200I, 38:253-257.
13. Lee SB, Kim SH, Bell DW, Wahrer DC, Schiripo TA, Jorczak MM, Sgroi DC, Garber JE, Li FP, Nichols KE, Varley JM, Godwin AK, Shannon KM, Harlow E, Haber DA: Destabilization of CHK2 by a missense mutation associated with Li- Fraumeni Syndrome. Cancer Res 2001, 6 1:8062-8067.

14. Vahteristo $P$, Tamminen A, Karvinen $P$, Eerola $H$, Eklund $C$, Aaltonen LA, Blomqvist C, Aittomaki K, Nevanlinna H: p53, CHK2, and CHKI genes in Finnish families with Li-Fraumeni syndrome: further evidence of CHK2 in inherited cancer predisposition. Cancer Res 2001, 6 I:5718-5722.

15. Sodha N, Houlston RS, Bullock S, Yuille MA, Chu C, Turner G, Eeles RA: Increasing evidence that germline mutations in CHEK2 do not cause Li- Fraumeni syndrome. Hum Mutat 2002, 20:460-462.

16. Siddiqui R, Onel K, Facio F, Nafa K, Diaz LR, Kauff N, Huang H, Robson $M$, Ellis N, Offit K: The TP53 mutational spectrum and frequency of CHEK2*IIO0delC in Li-Fraumeni-like kindreds. Fam Cancer 2005, 4: I77- I8I.

17. Walsh T, Casadei S, Coats KH, Swisher E, Stray SM, Higgins J, Roach KC, Mandell J, Lee MK, Ciernikova S, Foretova L, Soucek P, King MC: Spectrum of mutations in BRCAI, BRCA2, CHEK2, and TP53 in families at high risk of breast cancer. JAMA 2006, 295: $1379-1388$

18. Evans DG, Birch JM, Narod SA: Is CHEK2 a cause of the Li-Fraumeni syndrome? J Med Genet 2008, 45:63-64.

19. Meijers-Heijboer $\mathrm{H}$, Ouweland $\mathrm{A}$ van den, Klijn J, Wasielewski M, de Snoo A, Oldenburg R, Hollestelle A, Houben M, Crepin E, VeghelPlandsoen M, Elstrodt F, van Duijn C, Bartels C, Meijers C, Schutte M, McGuffog L, Thompson D, Easton D, Sodha N, Seal S, Barfoot R, Mangion J, Chang-Claude J, Eccles D, Eeles R, Evans DG, Houlston R, Murday V, Narod S, Peretz T, Peto J, Phelan C, Zhang HX, Szabo C, Devilee P, Goldgar D, Futreal PA, Nathanson KL, Weber B, Rahman $N$, Stratton MR: Low-penetrance susceptibility to breast cancer due to CHEK2(*)I I00delC in noncarriers of BRCAI or BRCA2 mutations. Nat Genet 2002, 3 I:55-59.

20. Vahteristo P, Bartkova J, Eerola H, Syrjakoski K, Ojala S, Kilpivaara O, Tamminen A, Kononen J, Aittomaki K, Heikkila P, Holli K, Blomqvist C, Bartek J, Kallioniemi OP, Nevanlinna H: A CHEK2 genetic variant contributing to a substantial fraction of familial breast cancer. Am J Hum Genet 2002, 7 I:432-438.

21. Weischer M, Bojesen SE, Ellervik C, Tybjaerg-Hansen A, Nordestgaard BG: CHEK2*I I O0delC genotyping for clinical assessment of breast cancer risk: meta-analyses of 26,000 patient cases and 27,000 controls. J Clin Oncol 2008, 26:542-548.

22. Offit K, Garber JE: Time to check CHEK2 in families with breast cancer? J Clin Oncol 2008, 26:519-520.

23. Meijers-Heijboer $H$, Wijnen J, Vasen $H$, Wasielewski M, Wagner A Hollestelle A, Elstrodt F, Bos R Van Den, de Snoo A, Tjon AF, Brekelmans $C$, Jagmohan S, Franken P, Verkuijlen $P$, Ouweland $A$ van den, Chapman P, Tops C, Moslein G, Burn J, Lynch H, Klijn J, Fodde R, Schutte M: The CHEK2 I I 00delC Mutation Identifies Families with a Hereditary Breast and Colorectal Cancer Phenotype. Am J Hum Genet 2003, 72: I308-1314.

24. Osorio A, Rodriguez-Lopez R, Diez O, de la Hoya M, Ignacio Martinez J, Vega A, Esteban-Cardenosa E, Alonso C, Caldes T, Benitez J: The breast cancer low-penetrance allele I I00delC in the CHEK2 gene is not present in Spanish familial breast cancer population. Int J Cancer 2004, I 08:54-56.

25. Hogervorst FBL, Nederlof PM, Gille JJP, McElgunn CJ, Grippeling M, Pruntel R, Regnerus R, van Welsem T, van Spaendonk R, Menko FH, Kluijt I, Dommering C, Verhoef S, Schouten JP, van't Veer LJ, Pals G: Large Genomic Deletions and Duplications in the BRCAI Gene Identified by a Novel Quantitative Method. Cancer Research 2003, 63:1449-|453.

26. Broeks A, de Witte L, Nooijen A, Huseinovic A, Klijn JG, van Leeuwen FE, Russell NS, van't Veer LJ: Excess risk for contralateral breast cancer in CHEK2* I I 00delC germline mutation carriers. Breast Cancer Res Treat 2004, 83:91-93.

27. Hubbard T, Andrews D, Caccamo M, Cameron G, Chen Y, Clamp M, Clarke L, Coates G, Cox T, Cunningham F, Curwen V, Cutts T, Down $T$, Durbin R, Fernandez-Suarez XM, Gilbert J, Hammond M, Herrero J. Hotz H, Howe K, lyer V, Jekosch K, Kahari A, Kasprzyk A, Keefe D, Keenan S, Kokocinsci F, London D, Longden I, McVicker G, Melsopp C, Meidl P, Potter S, Proctor G, Rae M, Rios D, Schuster M, Searle S, Severin J, Slater G, Smedley D, Smith J, Spooner W, Stabenau A, Stalker J, Storey R, Trevanion S, Ureta-Vidal A, Vogel J, White S, 
Woodwark C, Birney E: Ensembl 2005. Nucleic Acids Res 2005, 33:D447-D453.

28. Bogdanova N, Enssen-Dubrowinskaja N, Feshchenko S, Lazjuk GI, Rogov YI, Dammann O, Bremer M, Karstens JH, Sohn C, Dork T: Association of two mutations in the CHEK2 gene with breast cancer. Int / Cancer 2005, I I 6:263-266.

29. Kilpivaara O, Vahteristo P, Falck J, Syrjakoski K, Eerola H, Easton D, Bartkova J, Lukas J, Heikkila P, Aittomaki K, Holli K, Blomqvist C, Kallioniemi OP, Bartek J, Nevanlinna H: CHEK2 variant II57T may be associated with increased breast cancer risk. Int J Cancer 2004, II I:543-547.

30. Gorski B, Cybulski C, Huzarski T, Byrski T, Gronwald J, Jakubowska A, Stawicka M, Gozdecka-Grodecka S, Szwiec M, Urbanski K, Mitus J, Marczyk E, Dziuba J, Wandzel P, Surdyka D, Haus O, Janiszewska $H$, Debniak T, Toloczko-Grabarek A, Medrek K, Masojc B, Mierzejewski M, Kowalska E, Narod SA, Lubinski J: Breast cancer predisposing alleles in Poland. Breast Cancer Res Treat 2005, 92:19-24.

31. Dufault MR, Betz B, Wappenschmidt B, Hofmann W, Bandick K, Golla A, Pietschmann A, Nestle-Kramling C, Rhiem K, Huttner C, von LC, Dall P, Kiechle M, Untch M, Jonat W, Meindl A, Scherneck S, Niederacher D, Schmutzler RK, Arnold N: Limited relevance of the CHEK2 gene in hereditary breast cancer. Int J Cancer 2004, I 1 0:320-325.

32. Cybulski C, Gorski B, Huzarski T, Masojc B, Mierzejewski M, Debniak T, Teodorczyk U, Byrski T, Gronwald J, Matyjasik J, Zlowocka E, Lenner M, Grabowska E, Nej K, Castaneda J, Medrek K, Szymanska A, Szymanska J, Kurzawski G, Suchy J, Oszurek O, Witek A, Narod SA, Lubinski J: CHEK2 is a multiorgan cancer susceptibility gene. Am J Hum Genet 2004, 75: I I 3 I- I 135.

33. Stone JG, Eeles RA, Sodha N, Murday V, Sheriden E, Houlston RS: Analysis of Li-Fraumeni syndrome and Li-Fraumeni-like families for germline mutations in Bcll0. Cancer Lett 1999, 147:181-185.

34. Burt EC, McGown G, Thorncroft M, James LA, Birch JM, Varley JM: Exclusion of the genes CDKN2 and PTEN as causative gene defects in $\mathrm{Li}$ - Fraumeni syndrome. $\mathrm{Br} J$ Cancer 1999, 80:9-10.

35. Portwine C, Lees J, Verselis S, Li FP, Malkin D: Absence of germline pI6(INK4a) alterations in p53 wild type Li-Fraumeni syndrome families. J Med Genet 2000, 37:EI3.

36. Brown LT, Sexsmith E, Malkin D: Identification of a novel PTEN intronic deletion in Li-Fraumeni syndrome and its effect on RNA processing. Cancer Genet Cytogenet 2000, I 23:65-68.

37. Barlow JW, Mous M, Wiley JC, Varley JM, Lozano G, Strong LC, Malkin D: Germ line BAX alterations are infrequent in Li-Fraumeni syndrome. Cancer Epidemiol Biomarkers Prev 2004, 13:1403-1406.

38. Bond GL, Hu W, Bond EE, Robins H, Lutzker SG, Arva NC, Bargonetti J, Bartel F, Taubert H, Wuerl P, Onel K, Yip L, Hwang SJ, Strong LC, Lozano G, Levine AJ: A single nucleotide polymorphism in the MDM2 promoter attenuates the $\mathrm{p} 53$ tumor suppressor pathway and accelerates tumor formation in humans. Cell 2004, I19:591-602.

39. Bougeard G, Baert-Desurmont S, Tournier I, Vasseur S, Martin C, Brugieres L, Chompret A, Bressac-de Paillerets B, Stoppa-Lyonnet D, Bonaiti-Pellie C, Frebourg T: Impact of the MDM2 SNP309 and TP53 Arg72Pro polymorphism on age of tumour onset in LiFraumeni syndrome. J Med Genet 2005.

40. Tabori U, Malkin D: Risk stratification in cancer predisposition syndromes: lessons learned from novel molecular developments in Li-Fraumeni syndrome. Cancer Res 2008, 68:2053-2057

4I. Ruijs MW, Schmidt MK, Nevanlinna H, Tommiska J, Aittomaki K, Pruntel R, Verhoef $S$, Van't Veer LJ: The single-nucleotide polymorphism 309 in the MDM2 gene contributes to the Li-Fraumeni syndrome and related phenotypes. Eur J Hum Genet 2007, 15:110-I|14.
Publish with Biomed Central and every scientist can read your work free of charge

"BioMed Central will be the most significant development for disseminating the results of biomedical research in our lifetime. "

Sir Paul Nurse, Cancer Research UK

Your research papers will be:

- available free of charge to the entire biomedical community

- peer reviewed and published immediately upon acceptance

- cited in PubMed and archived on PubMed Central

- yours - you keep the copyright

Submit your manuscript here:

http://www.biomedcentral.com/info/publishing_adv.asp
BioMedcentral 